\title{
Fluxo gênico recíproco entre cultivares de soja convencional e geneticamente modificada
}

\author{
Welison Andrade Pereira(1), Filipe Luis Sávio(2), Denise Cunha Fernandes dos Santos Dias ${ }^{(1)}$, \\ Cosme Damião Cruz ${ }^{(1)}$ e Aluízio Borém ${ }^{(1)}$
}

\begin{abstract}
(1)Universidade Federal de Viçosa, Avenida P.H. Rolfs, s/no, CEP 36570-000 Viçosa, MG. E-mail: welison.pereira@ufv.br, dcdias@ufv.br, cdcruz@ufv.br, borem@ufv.br (2)Universidade de São Paulo, Escola Superior de Agricultura Luiz de Queiroz, Avenida Pádua Dias, no 11, CEP 13418-900 Piracicaba, SP. E-mail: filipe.savio@usp.br
\end{abstract}

Resumo - O objetivo deste trabalho foi determinar o fluxo gênico recíproco entre duas cultivares de soja, uma tolerante e outra sensível ao glifosato, além de aplicar estimadores para determinar a taxa de fecundação cruzada na população e o número de sementes híbridas na progênie. O experimento compôs-se de quatro blocos com 40 fileiras de soja, com 20 fileiras de cada cultivar (CD217 e CD219RR). No estádio R8, cinco fileiras, distantes 0,5, 1, 2, 4 e 8 m da cultivar adjacente, foram colhidas, trilhadas e analisadas quanto à ocorrência de fluxo gênico. Como características marcadoras, foram utilizadas as cores da flor, hipocótilo e pubescência, e a tolerância ao glifosato. As cultivares contrastam quanto às características analisadas, cada uma condicionada por um gene com dois alelos, em interação de dominância completa. Na progênie da cultivar tolerante, a maior taxa de híbridos encontrada foi $0,27 \%$ e, na progênie da cultivar sensível, identificou-se $0,83 \%$; pela hipótese do efeito diluição, as taxas de hibridação natural populacional seriam $0,104 \mathrm{e}$ $0,388 \%$, respectivamente. O fluxo gênico recíproco entre as cultivares CD217 e CD219RR não é o mesmo em ambas as direções. Os estimadores propostos são úteis para determinar a taxa de híbridos em amostras de sementes.

Termos para indexação: Glycine max, fecundação cruzada, tolerância ao glifosato, OGM.

\section{Reciprocal gene flow between conventional and genetically modified soybean cultivars}

\begin{abstract}
The objective of this work was to determine the reciprocal gene flow between two soybean cultivars, one tolerant and the other sensitive to glyphosate, as well as to use estimators to determine the outcrossing rate in the population and the number of hybrid seeds in the progeny. The experiment was composed of four blocks of 40 soybean rows, of which 20 rows of each cultivar (CD217 and CD219RR). At the R8 stage, five rows, distant 0.5, 1, 2, 4 and $8 \mathrm{~m}$ from the adjacent cultivar, were harvested, threshed and analyzed as for the occurrence of gene flow. As phenotypical markers, the trait color of flowers, hypocotil and pubescence, as well as the tolerance to glyphosate were used. The cultivars contrast for all the analyzed traits, each one conditioned by a single gene with two alleles, in a complete dominance interaction. In the tolerant cultivar progeny, the largest outcross rate was $0.27 \%$, and in the sensitive cultivar progeny, $0.83 \%$ was identified; by the dilution effect hypothesis, the outcross rates in natural populations would be 0.104 and $0.388 \%$, respectively. The reciprocal gene flow between CD217 and CD219RR cultivars is not the same in both directions. The proposed estimators are useful for determining the hybrid rates in seed samples.
\end{abstract}

Index terms: Glycine max, outcross, glyphosate tolerance, GMO.

\section{Introdução}

A soja (Glycine max (L.) Merrill) é uma espécie autógama e manifesta cleistogamia, ou seja, autopolinização antes da antese. No período anterior à abertura floral, as anteras liberam os grãos de pólen que caem no estigma da mesma flor (Carlson \& Lersten, 2004), portanto, quando as flores se encontram abertas, o processo de autofecundação já ocorreu. Ainda que a taxa de hibridação natural em autógamas seja baixa, o risco de escape gênico não é descartado. Receia-se que transgenes de indivíduos geneticamente modificados possam chegar a áreas de preservação ou reservas ecológicas e contribuir para o surgimento de invasoras (Schuster et al., 2007). Todavia, pesquisas de monitoramento de plantas geneticamente modificadas (GM), no ambiente - canola, milho, beterraba e batata - mostraram que a chance de este risco se concretizar é pequena, em razão do reduzido vigor de plantas domesticadas, em um ambiente competitivo (Crawley et al., 2001).

Eventos em que transgenes encontrados em cultivares comerciais cheguem às espécies silvestres e desencadeiem desequilíbrios ecológicos constituem 
preocupações quanto às variedades GM. No Brasil, especificamente, em se tratando de soja, este risco não deve ser considerado negligenciável, dada a inexistência de outras espécies sexuadamente compatíveis com Glycine max no País (Borém \& Miranda, 2009). Assim, cuidados que previnam o fluxo gênico entre cultivares, nos campos de produção de sementes, são necessários. A legislação para a produção e a comercialização de sementes tem normas de orientação às empresas produtoras, quanto aos procedimentos para a manutenção da pureza genética das sementes produzidas (Brasil, 2005). Além disso, em virtude da expansão da adoção das cultivares $\mathrm{GM}$, as pesquisas norteiam os órgãos fiscalizadores e certificadores, responsáveis pelo estabelecimento e regulamentação do manejo adequado à manutenção da pureza genética das cultivares.

Apesar de as pesquisas e revisões sobre o fluxo gênico em soja, já há algum tempo, terem sido publicadas (Vernetti et al., 1972), houve, recentemente, demanda para novos estudos, em consequência da chegada das cultivares GM (Abud et al., 2003; Pereira et al., 2007; Schuster et al., 2007). Os novos estudos investigaram a taxa de fecundação cruzada ou escape gênico da cultivar GM para uma convencional. No entanto, interessa aos pesquisadores e produtores de sementes conhecer a taxa de fecundação cruzada recíproca, entre cultivares plantadas lado a lado, bem como a distância mínima em que episódios de fecundação cruzada deixam de acontecer. É de interesse, também, a disponibilidade de metodologias rápidas e de baixo custo, que possibilitem a certificação de pureza genética em diferentes momentos, seja durante o ciclo da lavoura ou na análise das sementes armazenadas (Cunha et al., 2005).

Boerma \& Moradshahi (1975) sugerem que a quantidade total de plantas híbridas, em duas populações adjacentes em campo, seja estimada pelo dobro da quantidade observada de plantas híbridas em uma dessas populações. Isto pressupõe que a mesma quantidade de pólen transportado em uma direção no campo, o seria na direção oposta. Entretanto, isto é questionável, pois, sabe-se que a taxa de fecundação cruzada é influenciada por diversos fatores, entre eles: cultivar, local (Pereira et al., 2007), ano (Yoshimura et al., 2006), distância entre plantas e manejo de pragas (Abud et al., 2003).

O objetivo deste trabalho foi determinar o fluxo gênico recíproco entre duas cultivares de soja, uma tolerante e outra sensível ao glifosato, além de aplicar estimadores para determinar a taxa de fecundação cruzada na população e o número de sementes híbridas na progênie.

\section{Material e Métodos}

As cultivares de soja avaliadas (CD217 e CD219RR) divergem quanto a algumas características (Tabela 1), cujo controle genético é monogênico, com dois alelos em interação de dominância completa, o que torna a detecção de híbridos rápida e conclusiva. A cultivar CD217 tem alelos dominantes quanto às características cor da flor, cor do hipocótilo, cor do hilo e cor da pubescência, enquanto a cultivar CD219RR possui alelo dominante quanto à tolerância ao herbicida glifosato (Destro et al., 1990; Padgette et al., 1995; Cultivares de soja RR, 2005; Guia de produtos 2005, 2005).

O experimento foi implantado na safra 2007/2008, no campo experimental da Universidade Federal de Viçosa, em Viçosa, MG $\left(20^{\circ} 45^{\prime} 14 " \mathrm{~S}, 42^{\circ} 52^{\prime} 55^{\prime \prime} \mathrm{W}\right.$, altitude de $648 \mathrm{~m}$ ), em quatro blocos, com 40 fileiras (parcelas) de 5,0 m de comprimento, das quais 20 fileiras da cultivar CD217 e 20 da CD219RR. Os blocos foram distanciados em 1,0 $\mathrm{m}$ do bloco vizinho, conforme croqui (Figura 1). Não houve sorteio do lado onde foi plantada cada cultivar, pois, no presente trabalho, não foi avaliado o efeito do vento. Não houve sorteio em cada bloco, pois, neste caso, as duas populações ficariam lado a lado, em algumas posições do experimento, o que diminuiria a distância entre elas.

Para propiciar condições favoráveis à ocorrência do fluxo gênico recíproco, a sincronia do florescimento foi programada por meio do plantio escalonado

Tabela 1. Características descritoras das cultivares de soja CD217 e CD219RR.

\begin{tabular}{lcc}
\hline Característica & CD217 & CD219RR \\
\hline Ciclo total (média em dias) & $116(\mathrm{MG})$ & $122(\mathrm{MG})$ \\
Ciclo vegetativo (média em dias) & $54(\mathrm{MG})$ & $51(\mathrm{MG})$ \\
Cor da flor & Roxa $^{(1)}$ & Branca \\
Cor do hipocótilo & Roxa $^{(1)}$ & Verde \\
Cor da pubescência & Marrom $^{(1)}$ & Cinza \\
Cor do hilo & Preta $^{(1)}$ & Marrom clara \\
Altura média de planta (cm) & 71 & 78 \\
Hábito de crescimento & Determinado & Determinado \\
Tolerância ao herbicida & Sensível & Tolerante \\
\hline
\end{tabular}

${ }^{(1)}$ Característica monogênica dominante utilizada como marcador. Fonte: Cultivares de Soja RR (2005) e Guia de produtos 2005 (2005). 
das cultivares. Os plantios das cultivares CD217 e CD219RR se deram, respectivamente, nos dias 5 e 8 de dezembro de 2007, de modo que os períodos de florescimento coincidissem, de acordo com os descritores das cultivares (Tabela 1). Época, densidade de semeadura, adubação, manejo de insetos, entre
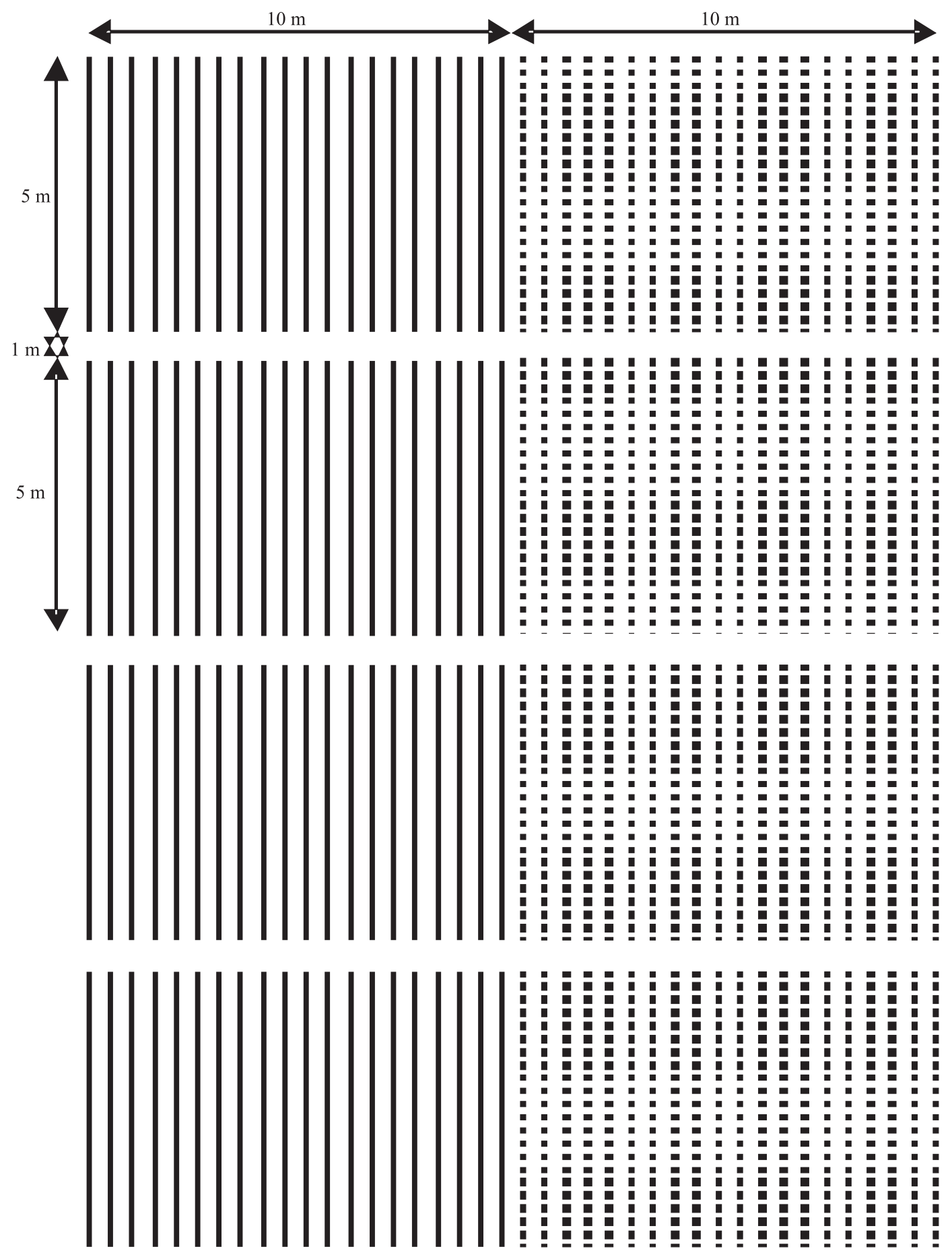

Figura 1. Croqui do experimento. Blocos com linhas contínuas e tracejadas representam as fileiras de plantas das cultivares de soja CD217 e CD219RR, respectivamente. A 1a, 2a, 4a, 8a e 16a fileiras, contadas a partir da cultivar adjacente, foram colhidas para a análise do fluxo gênico em função da distância. 
outras práticas culturais, foram feitas de acordo com as recomendações para plantio de soja no Estado de Minas Gerais (Tecnologias de produção de soja, 2003). Entretanto, inseticidas não foram aplicados durante o período de florescimento.

Durante o ciclo da cultura, foram realizadas vistorias para confirmar a pureza genética das cultivares. No preparo das sementes para o plantio, a cor do hilo foi usada para verificar a ocorrência de misturas. O florescimento simultâneo das cultivares avaliadas foi confirmado em outra vistoria, bem como a ausência de plantas com flor de cor diferente para cada variedade. A cor da pubescência também foi vistoriada nos estádios R7 (amarelecimento das folhas e vagens) e R8 (95\% das vagens maduras e desfolha das plantas) (Tecnologias de produção de soja, 2003).

No estádio R8, foram colhidas, de ambas as cultivares, cinco fileiras (parcelas) de cada bloco - na 1르, 2 $2^{\mathrm{a}}, 4^{\mathrm{a}}, 8^{\mathrm{a}}$ e $16^{\mathrm{a}}$ fileiras, contadas a partir da variedade adjacente e distantes $0,5,1,2,4$ e $8 \mathrm{~m}$ da primeira fileira da cultivar adjacente. Antes de trilhar o material colhido, a trilhadeira foi rigorosamente examinada quanto à existência de outras sementes e, após a trilhagem de cada fileira, a máquina era novamente vistoriada, para prevenir misturas acidentais. A ordem estabelecida para a trilhagem foi sequencial, começou na $16^{\mathrm{a}}$ e foi até a $1^{\mathrm{a}}$ fileira. Deste modo, mesmo que alguma semente viesse a permanecer na máquina após cada limpeza, isto não comprometeria os resultados, pois a probabilidade de ocorrência de fluxo gênico se reduz com a distância. As sementes obtidas foram armazenadas em câmara fria, com temperatura e umidade controladas, até a realização das análises subsequentes.

O tamanho mínimo da amostra avaliada, em cada fileira (parcela experimental), de cada bloco, foi calculado pela fórmula $\mathrm{n}=[\log (1-\mathrm{P})] /[\log (1-\mathrm{p})]$, em que: $\mathrm{n}$ é o tamanho da amostra; P é a probabilidade de ocorrência de pelo menos um determinado evento na população em estudo; e p é a probabilidade de ocorrência de tal evento, ou seja, a taxa de fecundação cruzada esperada (Pereira et al., 2007). As taxas de fecundação cruzada em soja variam entre 0,00 e 2,43\% (Vernetti et al., 1972). No presente trabalho, admitiu-se a fecundação cruzada esperada $(p)$ em $0,525 \%$, correspondente à média dos valores encontrados na literatura. Tendo-se adotado $\mathrm{P}=0,99$ e $\mathrm{p}=0,00525$, o tamanho mínimo da amostra encontrado foi de 875, o que determinou, em algumas metodologias, a adoção de amostras maiores, no intuito de se garantir a obtenção do número mínimo necessário de indivíduos para avaliação.

$\mathrm{O}$ estudo do fluxo gênico recíproco demandou métodos para se investigar a progênie nas duas cultivares. Para análise da cultivar CD219RR, três características morfológicas foram utilizadas como marcadoras: a cor da flor pleiotrópica com a cor do hipocótilo; e a cor da pubescência da vagem. Na cultivar CD217, a característica marcadora de hibridação foi a tolerância ao glifosato. Com base na literatura, quatro métodos foram adaptados e utilizados: verificação da cor da flor; verificação da cor do hipocótilo e pubescência; germinação em substrato umedecido com herbicida; e pulverização de plântulas com herbicida na pós-emergência.

Para verificação da cor da flor, na safra 2008/2009, na geração $\mathrm{F}_{1}, 1.500$ sementes por parcela experimental da cultivar CD219RR foram semeadas em campo. Durante o seu florescimento, avaliou-se a ocorrência de flores roxas, característica indicativa de fluxo gênico (Ray et al., 2003). Nos estádios R7 e R8, nova avaliação foi feita, e foi verificada a cor marrom da pubescência das vagens. Plantas com evidências de hibridação foram contabilizadas, e suas sementes coletadas. Para validar a identificação dos híbridos neste ensaio, a segregação na geração $F_{2}$ foi investigada. As sementes de cada planta híbrida foram semeadas em bandejas que continham areia estéril e, dez dias após a emergência, analisou-se a cor do hipocótilo. Apesar de a frequência 3:1 ser esperada na geração $F_{2}$, o surgimento de pelo menos uma plântula com hipocótilo verde já seria indicativo da condição híbrida da planta mãe.

Para verificação da cor do hipocótilo, de cada parcela experimental (cada linha) da variedade CD219RR, 1.000 sementes foram semeadas em leito de areia. Em bandejas de plástico com $38 \times 25 \times 7 \mathrm{~cm}$, que continham $3 \mathrm{~kg}$ de areia, foram distribuídas 250 sementes, em seis sulcos, com 42 sementes cada. Entre 10 e 15 dias após a semeadura, foi feita a avaliação (Destro et al., 1990). Plântulas com hipocótilos de cor roxa - correspondente ao fluxo gênico - foram computadas, transplantadas para vasos com substrato comercial, e mantidas em casa de vegetação até o final do ciclo. Durante esse período, a cor roxa da flor e a cor marrom da pubescência deveriam ser visualizadas. Ao final do ciclo, as sementes de cada planta foram coletadas e semeadas em leito de areia, para observação da segregação em $F_{2}$ de sua progênie. 
Este ensaio apresentou algumas vantagens de ordem prática sobre aquele realizado em campo, como economia de espaço, mão de obra e tempo para instalação do experimento em casa de vegetação. No experimento de campo, foi necessário aguardar o florescimento para as análises, enquanto no experimento em casa de vegetação, aguardou-se apenas a emergência das plântulas em leito de areia, pois em campo, há mais influência ambiental sobre o desenvolvimento das plantas (ataque de patógenos, pragas e doenças). Como as amostras avaliadas foram obtidas do mesmo modo, todas estas vantagens contribuíram para uma análise mais minuciosa e confiável quanto à presença de sementes híbridas.

Para a avaliação da resistência ao herbicida, na progê-nie da cultivar CD217, amostras de 1.500 sementes, de cada parcela experimental (cinco linhas), foram semeadas em bandejas de $38 \times 25 \times 7 \mathrm{~cm}$ que continham $3 \mathrm{~kg}$ de areia. Em cada bandeja, foram formados seis sulcos, nos quais foram distribuídas 50 sementes. No décimo segundo dia após o plantio, o herbicida glifosato foi aplicado sobre as plântulas, na dose de $4 \mathrm{~L} \mathrm{ha}^{-1}$ e volume de calda de $150 \mathrm{~L} \mathrm{ha}^{-1}$ (Miranda et al., 2006). Duas semanas após a aplicação do herbicida, as plântulas foram analisadas. Indivíduos sensíveis entraram em senescência, e indivíduos tolerantes se mantiveram com vitalidade, o que é indício de hibridação. Schuster et al. (2007) também utilizaram a pulverização de plântulas aos 15 dias de emergência, como método para a identificação de híbridos, em estudo de fluxo gênico de uma cultivar tolerante e outra sensível ao herbicida glifosato.

Para a avaliação da germinação das sementes, em substrato com herbicida glifosato, amostras de 900 sementes, de cada parcela experimental (cinco linhas), foram distribuídas em 18 rolos de papel germitest e mantidas em BOD $\left(25 \pm 1^{\circ} \mathrm{C}\right)$ por sete dias. O método consistiu em umedecer o papel germitest com solução a $0,03 \%$ do equivalente ácido do herbicida, na proporção de três vezes a massa do papel seco. Plântulas normais foram computadas como resultantes de fluxo gênico. Plântulas anormais, com processo germinativo interrompido, também foram analisadas, pois, é possível caracterizar plântulas anormais tolerantes ao glifosato (Pereira et al., 2009). Plântulas da cultivar sensível ao glifosato caracterizam-se pela ausência de raízes secundárias; sua raiz primária apresenta engrossamento em relação ao seu comprimento (Pereira et al., 2009).
O delineamento experimental, para a avaliação da taxa de fecundação cruzada em diferentes distanciamentos, foi inteiramente casualizado com quatro repetições, em todos os métodos: cor da flor e do hipocótilo; tolerância de plântulas à pulverização com glifosato; e germinação em substrato umedecido com herbicida. Procedeu-se às análises de variância e de regressão, sem transformação de dados, tendo-se em vista $\mathrm{o}$ atendimento das pressuposições de normalidade e homogeneidade de variância. A partir das taxas de fecundação cruzada em função da distância, foi possível identificar o modelo que melhor explica os resultados, tendo-se utilizado como critério o maior coeficiente de determinação. As equações foram ajustadas pelas médias das quatro repetições de cada tratamento, e os dados foram analisados com o auxílio do aplicativo Genes (Cruz, 2001).

Após a obtenção da taxa de fecundação cruzada, ou seja, quantidade de sementes híbridas em cada tratamento (distância de uma cultivar para a outra), procedeu-se à estimativa da taxa de fecundação cruzada do bloco, ou seja, da população à qual pertencia cada amostra. Tem-se observado que estudos de fluxo gênico se limitam a informar a taxa de sementes híbridas das fileiras analisadas e a ignorar o tamanho da população. Apesar de esta informação não ser incorreta, ela pode superestimar a quantidade de híbridos numa análise superficial. Como o estande total supera o número de indivíduos avaliados nas bordas do experimento, onde ocorrem os eventos de fluxo gênico, espera-se que o valor encontrado para a taxa de fecundação cruzada populacional seja inferior ao da taxa de fecundação cruzada de uma única fileira. Schuster et al. (2007) também chamaram a atenção para este fato. Se a taxa de fecundação cruzada for de $1 \%$, estimada com base na primeira fileira da borda de uma lavoura, isto não quer dizer que $1 \%$ de híbridos serão encontrados na geração seguinte desta população, pois apenas uma fileira foi analisada. Assim, se propõe no presente trabalho a aplicação do efeito de diluição. Conforme a hipótese deste efeito, a quantidade de sementes híbridas em uma lavoura de soja reduz-se exponencialmente, à medida que aumenta o tamanho total da população. Em outras palavras, quanto maior a lavoura, maior a diluição dos contaminantes. Os estimadores a seguir, propostos no presente trabalho, foram utilizados para estimar tanto o percentual de fluxo gênico populacional, quanto o número de sementes híbridas na progênie, 


$$
\mathrm{FGPop}=\left(\sum \% \mathrm{FGFi}\right) / \mathrm{n},
$$

em que: FGPop é o fluxo gênico populacional; FGFi é o fluxo gênico na fileira i; e n é o número de fileiras (ou parcelas). O número de sementes híbridas é dado por,

$$
\mathrm{NSH}=\sum(\mathrm{FGFi} \times \mathrm{CFi} \times \mathrm{EFi} \times \overline{\mathrm{S}}),
$$

em que: NSH é o número de sementes híbridas; FGFi é o fluxo gênico na fileira i; CFi é o comprimento da fileira i; EFi é o estande na fileira i; e $\overline{\mathrm{S}}$ é o número médio de sementes por planta.

\section{Resultados e Discussão}

Durante o preparo das sementes para o plantio, não foi observada a ocorrência de mistura. Sementes de hilo preto foram encontradas apenas nas amostras da cultivar CD217, e sementes com hilo marrom claro apenas nas amostras da cultivar CD219RR. Houve sincronia de florescimento entre as cultivares, e verificouse a ocorrência de plantas com cor de flor e de pubescência características de cada cultivar, ou seja, flor branca e pubescência cinza, nas plantas da cultivar CD219RR, e flor roxa e pubescência marrom, nas plantas da cultivar CD217, o que evidencia pureza genética das cultivares.

À época do florescimento da progênie da cultivar CD219RR, algumas plantas com flores roxas foram encontradas. Segundo Destro et al. (1990), a cor da flor e a da pubescência são características marcadoras de hibridação porque são condicionadas por um par de alelos cada, em interação de dominância completa. A cor roxa da flor é condicionada pelo alelo $W$ enquanto o recessivo $w$ condiciona a cor branca. A cor marrom $(T)$ da pubescência é controlada por um par de alelos e é completamente dominante sobre a cor cinza $(t)$.

A taxa estimada de fluxo gênico de uma cultivar, à distância de $0,5 \mathrm{~m}$ da cultivar vizinha, foi de $0,13 \%$ (Figura 2 A). A $1 \mathrm{~m}$ de distância, a taxa continuou $0,13 \%$ e, a partir daí, não mais foram identificados casos de fecundação cruzada. Estes resultados são inferiores aos encontrados por Ray et al. (2003), que também utilizaram o método de verificação da cor da flor para a identificação de híbridos.
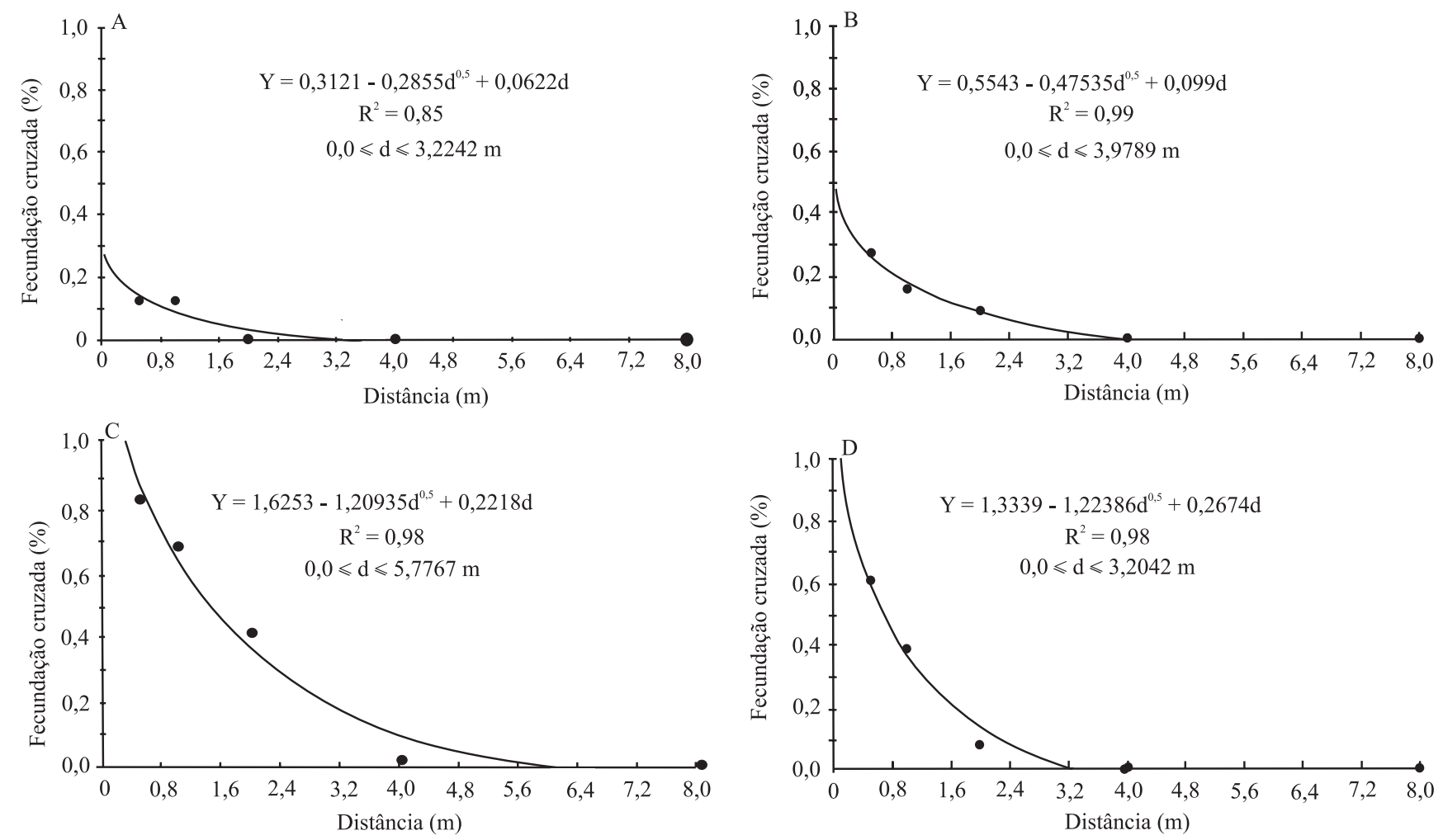

Figura 2. Análise de regressão, modelo raiz quadrada, para os dados coletados de fecundação cruzada, a partir dos métodos: A, verificação da cor da flor, em lavoura; B, verificação da cor do hipocótilo, em casa de vegetação; C, pulverização das plântulas com herbicida, em casa de vegetação; e D, germinação de sementes, em substrato umedecido com solução do herbicida; d, distância. 
O modelo raíz quadrada foi o que melhor explicou os resultados de fecundação cruzada, e que apresentou maior coeficiente de determinação. Pela curva de regressão (Figura $2 \mathrm{~A}$ ), verificou-se expectativa de taxa nula de fecundação cruzada a aproximadamente $1 \mathrm{~m}$ de distância da fonte de pólen contaminante, distância menor do que aquela recomendada pelo Ministério da Agricultura, Pecuária e Abastecimento (MAPA), para o isolamento entre campos de produção de sementes de soja (Brasil, 2005).

Das sementes coletadas de cada planta híbrida e semeadas em leito de areia, verificou-se segregação quanto à cor do hipocótilo, o que confirma o hibridismo em todas as plantas (Tabela 2). Contudo, nem sempre a segregação seguiu a proporção 3:1, em razão do reduzido número de sementes obtidas das plantas.

Conforme Destro et al. (1990), após a emergência das plântulas em leito de areia, é possível avaliar a cor do hipocótilo, como modo de identificar o fluxo gênico entre as cultivares, desde que contrastem quanto a este caráter. Plântulas com hipocótilo de cor roxa - indicativa de ocorrência de fecundação cruzada - foram identificadas, no presente trabalho, por meio do teste de emergência em leito de areia. A maior taxa de híbridos $(0,27 \%)$ foi encontrada em amostras de sementes das plantas que ficaram a $0,5 \mathrm{~m}$ da população vizinha e decaiu, progressivamente, a partir desta distância. A curva de regressão intercepta o eixo dos x em torno dos $2 \mathrm{~m}$ de distância, o que está de acordo com a recomendação do MAPA (Brasil, 2005), quanto ao isolamento entre campos de produção, para a manutenção da pureza genética de sementes de soja (Figura 2 B). Outros autores também verificaram redução brusca da taxa de hibridação natural, em plantas isoladas a partir dessa distância (Abud et al., 2003; Ray et al., 2003; Pereira et al., 2007; Schuster et al., 2007).

A análise da segregação quanto à cor do hipocótilo, na progênie das plântulas identificadas como híbridas, mostrou que elas foram corretamente identificadas (Tabela 3).

Tabela 2. Origem de cada planta coletada da população da cultivar de soja transgênica CD219RR, com flor de cor roxa, número de sementes obtidas a partir de cada planta, e segregação de sua progênie, quanto à cor do hipocótilo - roxo (WW ou Ww) ou verde (ww) -, em ensaio de emergência em leito de areia e teste de qui quadrado para a segregação 3:1.

\begin{tabular}{|c|c|c|c|c|c|}
\hline \multirow[t]{2}{*}{ Planta } & \multicolumn{3}{|c|}{ Progênie } & \multicolumn{2}{|c|}{ Segregação quanto à cor do hipocótilo } \\
\hline & Total de sementes & Roxo (WW ou Ww) & Verde (ww) & $\chi^{2}$ & Nível de significância $^{(1)}$ \\
\hline Fileira 1, bloco $1^{(2)}$ & 15 & 10 & 5 & 0,555 & 0,4560 \\
\hline Fileira 1, bloco 1 & 19 & 14 & 5 & 0,017 & 0,8946 \\
\hline Fileira 1, bloco 3 & 16 & 12 & 4 & 0,000 & 1,0000 \\
\hline Fileira 1, bloco 4 & 16 & 8 & 8 & 5,333 & 0,2090 \\
\hline Fileira 2, bloco 1 & 17 & 11 & 6 & 0,961 & 0,3269 \\
\hline Fileira 2, bloco 3 & 73 & 52 & 21 & 0,555 & 0,4573 \\
\hline Fileira 2, bloco 4 & 28 & 15 & 13 & 6,857 & 0,0088 \\
\hline
\end{tabular}

(1)Máxima probabilidade de rejeição da hipótese de segregação, pelo teste de qui quadrado. ${ }^{(2)}$ Fileira em cada um de quatro blocos, que continham 20 fileiras de cinco metros de comprimento, para cada cultivar.

Tabela 3. Origem de cada plântula identificada como híbrida, com hipocótilo roxo, número de sementes produzidas, número de sementes emergidas do leito de areia, segregação quanto à cor do hipocótilo - roxo (WW ou Ww) ou verde (ww) -, e teste de qui quadrado para segregação 3:1.

\begin{tabular}{|c|c|c|c|c|c|}
\hline \multirow[t]{2}{*}{ Planta } & \multirow{2}{*}{$\begin{array}{c}\text { Progênie } \\
\text { Total de sementes colhidas/emergidas }\end{array}$} & \multicolumn{2}{|c|}{ Cor do hipocótilo } & \multirow[t]{2}{*}{$\chi^{2}$} & \multirow[t]{2}{*}{ Nível de significância ${ }^{(1)}$} \\
\hline & & Roxo (WW ou Ww) & Verde (ww) & & \\
\hline Fileira 1, bloco $1^{(2)}$ & $149 / 113$ & 80 & 33 & 1,065 & 0,3021 \\
\hline Fileira 1, bloco 2 & $155 / 102$ & 72 & 30 & 1,059 & 0,3035 \\
\hline Fileira 1, bloco 2 & $105 / 89$ & 70 & 19 & 0,633 & 0,4263 \\
\hline Fileira 1, bloco 4 & $134 / 126$ & 98 & 28 & 0,518 & 0,4714 \\
\hline Fileira 1, bloco 4 & $137 / 115$ & 85 & 30 & 0,072 & 0,7877 \\
\hline Fileira 2, bloco 1 & $125 / 111$ & 83 & 28 & 0,003 & 0,9563 \\
\hline Fileira 2, bloco 3 & $144 / 125$ & 94 & 31 & 0,003 & 0,9588 \\
\hline Fileira 4, bloco 1 & $153 / 140$ & 107 & 33 & 0,152 & 0,6963 \\
\hline Fileira 4, bloco 4 & $145 / 123$ & 89 & 34 & 0,458 & 0,4986 \\
\hline
\end{tabular}

${ }^{(1)}$ Máxima probabilidade de rejeição da hipótese de segregação, pelo teste de qui quadrado. ${ }^{(2)}$ Fileira em cada um dos quatro blocos, que continham 20 fileiras de cinco metros de comprimento, para cada cultivar. 
Como já relatado, a cultivar CD217 é sensível ao glifosato, enquanto a CD219RR é tolerante. Caso ocorra uma planta híbrida na progênie da cultivar CD217, esta deverá apresentar a condição de tolerância ao glifosato, considerando-se a sua herança monogênica de dominância completa $\left(\mathrm{F}_{2}: 3: 1\right)$. Como esperado, as maiores taxas de fecundação cruzada ocorreram às menores distâncias entre cultivares (Abud et al., 2003; Ray et al., 2003; Yoshimura et al., 2006; Pereira et al., 2007; Schuster et al., 2007).

A pulverização de plântulas com herbicida, como método para detectar plântulas tolerantes, apresenta um índice de acerto superior a 92\% (Miranda et al., 2006). A taxa de fecundação cruzada foi de $0,68 \%$ a $1 \mathrm{~m}$ de distância da fonte de pólen. Schuster et al. (2007) encontraram $0,61 \%$ de híbridos a esta distância. A curva de regressão intercepta o ponto zero em distância inferior a $4 \mathrm{~m}$, o que mostra que o isolamento de cultivares por distância é eficiente para a manutenção da pureza genética de sementes de soja (Figura 2C).

Foi observada baixa taxa de fecundação cruzada, identificada pela germinação em solução do herbicida (Figura 2 D), e nos demais ensaios no presente trabalho, também relatada na literatura (Abud et al., 2003; Ray et al., 2003; Pereira et al., 2007; Schuster et al., 2007). Sementes de soja tolerantes ao herbicida germinam, normalmente, em papel germitest umedecido com solução do herbicida, enquanto sementes de cultivares sensíveis não o fazem (Pereira et al., 2009). Conforme a curva de regressão obtida (Figura 2 D), espera-se taxa de fluxo gênico nula, em torno dos $3 \mathrm{~m}$ de distância da fonte de pólen contaminante.

Concluiu-se que, a partir dos $3 \mathrm{~m}$ de distância, é pouco provável a ocorrência de fluxo gênico entre cultivares de soja, assim como verificado também por outros autores (Abud et al., 2003; Ray et al., 2003; Pereira et al., 2007), o que orienta o planejamento dos campos de produção de sementes.

A avaliação de caracteres morfológicos confirmou o hibridismo das plântulas, o que mostra que a análise morfológica é eficiente em estudos de hibridação natural (Pereira et al., 2007). Portanto, quando mais de uma característica passa a ser analisada, e a geração $F_{2}$ pode ser explorada, a avaliação ganha credibilidade.

A taxa de alogamia, mensurada a $0,5 \mathrm{~m}$ de distância de uma fonte de contaminação, variou 0,13 a $0,83 \%$ entre os métodos de detecção de híbridos. Assim, resultados distintos podem ser obtidos por diferentes métodos de detecção de híbridos, em especial quando se trata de eventos raros, como a fecundação cruzada em soja (Figura 2). Contudo, o fato de a cultivar ser transgênica não altera a expectativa de fluxo gênico - menor do que $1 \%$-, relatada na literatura (Pereira et al., 2007).

Com o estimador efeito de diluição para a taxa de fecundação cruzada populacional, foi possível estimar a percentagem de hibridação natural das cinco fileiras avaliadas de cada um dos quatro blocos. Para um estande de 14 plantas $\mathrm{m}^{-1}$ e 100 sementes por planta, seria estimada uma população de 35 mil sementes por bloco, o que totalizaria 140 mil sementes da progênie das cinco fileiras avaliadas. Entretanto, é importante relembrar que a população inteira do presente trabalho teve 20 fileiras, mas que foram avaliadas apenas as cinco fileiras amostradas.

$\mathrm{O}$ número estimado de sementes híbridas em um lote faz referência ao número de híbridos que seguem para a próxima geração. Conforme o resultado de cada método aplicado: verificação da cor da flor e da cor do hipocótilo, pulverização das plântulas com o herbicida e germinação das sementes em substrato umedecido com solução do herbicida, as quantidades de sementes híbridas esperadas, foram determinadas pelos estimadores (Tabela 4).

As sementes híbridas da cultivar sensível (CD217) apresentam, como propriedade, a biossíntese da versão bacteriana da enzima 5-enol-piruvil-shiquimato-3-fosfato-sintase (CP4 EPSPS), que é insensível à ação do glifosato

Tabela 4. Taxa de fluxo gênico populacional e número de sementes híbridas, no lote estimado de 140 mil sementes, com base nos métodos de detecção de híbridos utilizados, tendo-se tomado como referência as cinco fileiras de plantas de soja, com estande de 14 plantas por metro e 100 sementes por planta.

\begin{tabular}{lcc}
\hline Método & $\begin{array}{c}\text { Taxa de fluxo gênico } \\
\text { gênico populacional } \\
\text { (FGPop) }^{(1)}(\%)\end{array}$ & $\begin{array}{c}\text { Número de sementes } \\
\text { híbridas }(\mathrm{NSH})^{(2)}\end{array}$ \\
\hline Cor da flor & 0,052 & 73 \\
Cor do hipocótilo & 0,104 & 146 \\
Pulverização de plântulas & 0,388 & 543 \\
Germinação em papel & 0,216 & 302 \\
umedecido & & \\
\hline
\end{tabular}

${ }^{(1)} \mathrm{FGPop}=\left(\sum \% \mathrm{FGFi}\right) / \mathrm{n}$, em que: FGPop é o fluxo gênico populacional; FGFi é o fluxo gênico na fileira i; e $n$ é o número de fileiras. ${ }^{(2)} \mathrm{NSH}=\sum(\mathrm{FGFi} \times \mathrm{CFi} \times \mathrm{EFi} \times \overline{\mathrm{S}})$, em que: $\mathrm{NSH}$ é o número de sementes híbridas; FGFi é o fluxo gênico na fileira i; CFi é o comprimento da fileira i; EFi é o estande na fileira i; e $\overline{\mathrm{S}}$ é o número médio de sementes por planta. 
(Padgette et al., 1995). Contudo, tais indivíduos não levam vantagem sobre os demais, pois, numa lavoura de sementes convencionais, não se aplica o herbicida. Assim, é possível que o alelo transgênico seja perdido ao longo das gerações via deriva genética (Schuster et al., 2007). Além disso, como a maior taxa de híbridos se concentra nas fileiras próximas à vizinhança da cultivar adjacente, eliminar a borda de uma lavoura - atitude recomendada aos produtores de sementes (Brasil, 2005) -, pode praticamente eliminar o risco de sementes híbridas no lote de sementes. Pelas possibilidades já citadas, de escalonar o plantio de cultivares distintas, para prevenir a sincronia do florescimento, bem como, de isolar por distância duas populações, o produtor dispõe de práticas culturais eficientes para a manutenção da pureza genética de suas variedades.

Aaplicação do estimador de fluxo gênico populacional constitui um modo suplementar para analisar a taxa de fecundação cruzada, pois reduz o risco de que os dados sejam equivocadamente interpretados. Afirmar que a soja possui, em média, uma taxa de fecundação cruzada de $1 \%$ pode induzir ao julgamento errôneo de que esta seja, em média, a taxa de híbridos em um lote de sementes. Geralmente, as taxas de hibridações naturais publicadas se referem às fileiras ou amostras analisadas e não à população inteira. Portanto, em estudos desta natureza, é relevante informar o modo como uma amostra foi obtida e o significado dos resultados para as gerações seguintes.

\section{Conclusões}

1. O fluxo gênico recíproco entre as cultivares de soja CD217 e CD219RR não é o mesmo em ambas as direções.

2. Os estimadores propostos no presente trabalho são úteis para determinar a taxa de híbridos existente na amostra de sementes.

3. A distância entre cultivares de soja é um fator crítico para o isolamento reprodutivo, ao limitar a ocorrência de fluxo gênico entre cultivares.

4. A partir dos $3 \mathrm{~m}$ de distância entre cultivares, é rara a ocorrência de fluxo gênico.

\section{Agradecimentos}

Ao Conselho Nacional de Desenvolvimento Científico e Tecnológico, por concessão de bolsa; à Cooperativa Central de Pesquisa Agrícola, pela concessão do material genético para a realização deste trabalho.

\section{Referências}

ABUD, S.; SOUZA, P.I.M. de; MOREIRA, C.T.; ANDRADE, S.R.M.; ULBRICH, A.V.; VIANNA, G.R.; RECH, E.L.; ARAGÃO, F.J.L. Dispersão de pólen em soja transgênica na região do Cerrado. Pesquisa Agropecuária Brasileira, v.38, p.1229-1235, 2003.

BOERMA, H.R.; MORADSHAHI, A. Pollen movement within and between rows to male-sterile soybeans. Crop Science, v.15, p.858-861, 1975.

BORÉM, A.; MIRANDA, G.V. Melhoramento de plantas. 5.ed. Viçosa: UFV, 2009. 529p.

BRASIL. Ministério da Agricultura, Pecuária e Abastecimento. Instrução normativa no 25 de 16 de dezembro de 2005. Padrões para produção e comercialização de sementes de soja. Anexo IX. Diário Oficial [da] República Federativa do Brasil, 20 dez. 2005. Seção 1, p.18.

CARLSON, J.B.; LERSTEN, N.R. Reproductive morphology. In: BOERMA, R.; SPECHT, J.E. (Ed.). Soybeans: improvement, production, and uses. $3^{\text {rd }}$ ed. Madison: Soil Science Society of America, 2004. p.59-95.

CULTIVARES de soja RR. Cascavel: Coodetec, 2005. 15p.

CRAWLEY, M.J.; BROWN, S.L.; HAILS, R.S.; KOHN, D.D.; REES, M. Transgenic crop in natural habitats. Nature, v.409, p.682-683, 2001 .

CRUZ, C.D. Programa GENES: aplicativo computacional em genética e estatística: versão Windows. Viçosa: UFV, 2001. 648p.

CUNHA, C. dos S.M.; TILLMANN, M.A.A.; VILLELA, F.A.; DODE, L.B.; BALERINI, F. Comparação de métodos na detecção de sementes de soja geneticamente modificada resistente ao glifosato. Revista Brasileira de Sementes, v.27, p.167-175, 2005.

DESTRO, D.; SEDIYAMA, T.; GOMES, J.L.L. Genes qualitativos em soja: alguns comentários e listagem. Viçosa: UFV, 1990. 67p.

GUIA de produtos 2005. Cascavel: Coodetec, 2005. 125p.

MIRANDA, D.M. de; TILLMANN, M.A.A.; NOLDIN, J.A.; BALERINI, F. Bioensaio em casa-de-vegetação na detecção e quantificação de sementes de soja geneticamente modificada. Revista Brasileira de Sementes, v.28, p.187-192, 2006.

PADGETTE, S.R.; KOLACZ, K.H.; DELANNAY, X.; RE, D.B.; LaVALLEE, B.J.; TINIUS, C.N.; RHODES, W.K.; OTERO, Y.I.; BARRY, G.F.; EICHHOLTZ, D.A.; PESCHKE, V.M.; NIDA, D.L.; TAYLOR, N.B.; KISHORE, G.M. Development, identification, and characterization of a glyphosate-tolerant soybean line. Crop Science, v.35, p.1451-1461, 1995.

PEREIRA, W.A.; DEL GIÚDICE, M.P.; CARNEIRO, J.E. de S.; DIAS, D.C.F. dos S.; BORÉM, A. Fluxo gênico em soja geneticamente modificada e método para sua detecção. Pesquisa Agropecuária Brasileira, v.42, p.999-1006, 2007. 
PEREIRA, W.A.; LISBOA, S.P.; DIAS, D.C.F. dos S.; ALVARENGA, E.M.; BORÉM, A. Ajuste de metodologias para a identificação de cultivares de soja quanto à tolerância ao glifosato. Revista Brasileira de Sementes, v.31, p.133-144, 2009.

RAY, J.D.; KILEN, T.C.; ABEL, C.A.; PARIS, R.L. Soybean natural cross-pollination rates under field conditions. Environmental Biosafety Research, v.2, p.133-138, 2003.

SCHUSTER, I.; VIEIRA, E.S.N.; SANTANA, H.; SINHORAT, D.; SILVA, R.B. da; OLIVEIRA, M.A.R. Fluxo gênico em soja na Região Oeste do Paraná. Pesquisa Agropecuária Brasileira, v.42, p.515-520, 2007.
TECNOLOGIAS de produção de soja - região central do Brasil 2004. Londrina: Embrapa Soja, 2003. 237p. (Embrapa Soja. Sistemas de Produção, 4).

VERNETTI, F. de J.; BONATO, E.R.; TERESAWA, F.; GASTAL, M.F. da C. Observações sobre a taxa de cruzamentos naturais em soja, em Pelotas e Sertão, RS, e Ponta Grossa, PR. Ciência e Cultura, v.1, p.36-41, 1972.

YOSHIMURA, Y.; MATSUO, K.; YASUDA, K. Gene flow from GM glyphosate-tolerant to conventional soybeans under field conditions in Japan. Environmental Biosafety Research, v.5, p.169-173, 2006.

$\overline{\text { Recebido em } 16 \text { de agosto de } 2011 \text { e aprovado em } 29 \text { de dezembro de } 2011}$ 